\title{
A Meta\#analysis of the Willingness to Pay for Cultural Services from Grasslands in Europe
}

\section{Journal Article}

Author(s):

Huber, Robert; Finger, Robert (D)

Publication date:

2020-06

Permanent link:

https://doi.org/10.3929/ethz-b-000365448

Rights / license:

In Copyright - Non-Commercial Use Permitted

Originally published in:

Journal of Agricultural Economics 71(2), https://doi.org/10.1111/1477-9552.12361 


\title{
A Meta-analysis of the Willingness To Pay for Cul- tural Services from Grasslands in Europe
}

\author{
Robert Huber and Robert Finger ${ }^{1}$ \\ (Original submitted January 2019, revision received June 2019, accepted July 2019.)
}

\begin{abstract}
We investigate the willingness to pay (WTP) for cultural ecosystem services from grasslands using a meta-analysis based on 32 eligible research papers that provide in total 79 estimates. The average WTP (corrected for purchasing power) across these studies is 38 Euros per person per year. Yet, our analysis reveals that the transfer of these results needs careful evaluation. More specifically, it is essential to frame the monetary valuation exercise in relation to the direction of grassland change. A switch from cropland to grassland reduces WTP by 90 Euros while an increase in less-intensive land-use in mountain regions raises WTP by 53 Euros. We conclude that for an adequate consideration of grasslands in holistic ecosystem services assessments, the direction of grassland change is important.
\end{abstract}

Keywords: Willingness to pay (WTP); grasslands; cultural ecosystem services; meta-regression analysis.

JEL classifications: $Q 51, Q 57$.

DOI: $10.1111 / 1477-9552.12361$

\section{Introduction}

Grasslands are an important land-use type, covering about $40 \%$ of the earth's land surface (Blair et al., 2014). In Europe, permanent grassland accounts for about one third of the agricultural area (Estel et al., 2018). In mountainous regions, such as Switzerland, as much as two thirds of the agricultural area is grassland and forms the backbone of agricultural production (Mack and Huber, 2017). Grasslands also provide many ecosystem services (ES) such as fodder, carbon sequestration and biodiversity (Allan et al., 2015). Moreover, cultural ecosystem services such as aesthetic, heritage or recreational values have also become important categories in the ES

1 Robert Huber and Robert Finger are both with the Agricultural Economics and Policy Group, ETH, Zurich, Switzerland. Email: rhuber@ethz.ch for correspondence. This work is supported by an ETH research grant for the project VALUEGRASS. We are grateful for constructive comments from journal referees and the Editor on previous versions of this manuscript. 
framework (Plieninger et al., 2015). Valuation of grassland ES plays an important role in the management of multifunctional landscapes, e.g. in setting priorities for conservation efforts or agri-environmental measures through cost-benefit analysis (e.g. Albert et al., 2017; Manning et al., 2018; Randall, 2002;). This is especially relevant in the context of the European agricultural sector. For instance, the common agricultural policy focuses increasingly on environmental targets and uses agri-environmental measures to encourage farmers to protect and enhance grasslands and landscape features (Lefebvre et al., 2015; Pe'er et al., 2014). In Switzerland and Norway, farmers receive direct payments for grassland maintenance, in particular with regard to cultural landscapes in remote and mountain regions (e.g. Huber et al., 2017; Kvakkestad et al., 2015).

Marginality is one of the key concepts in the economic assessment of ES. The value of a particular ES is a function of (small) changes in land-use and associated ES provision flows (Fisher et al., 2008). Thus, assessments of changes in welfare must evaluate marginal changes rather than estimate total values of overall ES. These marginal changes in ES provision in grasslands occur at both the extensive and intensive margins. Changes at the extensive margin imply either an increase or decrease in the total amount of grassland. Examples are conversion to/from cropland, forest regrowth or land abandonment. Changes at the intensive margin imply a change in grassland intensities, i.e. the number of cuts, use of fertiliser, grazing intensity, species composition and diversity (Finger and Buchmann, 2015).

We contribute to understanding the value of grassland ES and associated changes by conducting a meta-analysis of the willingness to pay for cultural ES from grasslands in Europe. This fills important gaps in the literature. Firstly, no systematic review exists on the valuation of cultural ES from grasslands. Secondly, many existing economic assessments of grassland ES fail to account for the nature of changes at the extensive and intensive margins, i.e. whether the change reduces cropland, increases forest or affects the intensity within grasslands. Existing valuation studies often treat grassland changes as a one-dimensional development and do not account for the direction of change (Albert et al., 2017; Ciaian and Gomez y Paloma, 2011; Frélichová et al., 2014; Schägner et al., 2013; Schägner et al., 2018; van Zanten et al., 2014). Ignoring the direction of change may explain ambiguities in the findings of these studies. For example, some studies find that grasslands increase the value of landscapes, e.g. Ciaian and Gomez y Paloma (2011), while others find that they reduce the value of landscapes, e.g. Schägner et al. (2018).

We conduct a meta-regression analysis to synthesise existing empirical studies on the willingness to pay for cultural ES of European grasslands. We focus on European studies since the 
valuation of ES is central to European agricultural and rural polices. Moreover, this restriction allows us to maintain a set of comparable agricultural and socio-economic systems in the metaanalysis. Our dependent variable is based on the willingness to pay estimates for grassland reported in the literature, comprising both contingent valuation methods and discrete choice experiments studies. The variation of willingness to pay for grasslands across and within these studies is explained using several controls for specific methodological and case study differences. Most importantly, we also report whether these studies assessed i) grassland abandonment, ii) a change to more extensive grassland use, or iii) implied a switch from cropland to grassland. The remainder of this paper is structured as follows. We begin by outlining the background of cultural ecosystem services and stated preference valuation. Then, we present our data collection and methodical approach. We present our results in the third section, followed by a discussion of our findings and conclusions.

\section{Cultural Ecosystem Services and Stated Preference Valuation}

In the existing literature, cultural ecosystem services are classified in seven categories: aesthetics, cultural heritage, spiritual and religious values, recreation, educational, inspirational and sense of place (MEA, 2005; Daniel et al., 2012; Hernández-Morcillo et al., 2013). Moreover, the existence value of biodiversity and habitat is also often categorised as a cultural service (e.g. Elmqvist et al., 2010; Malinga et al., 2015). In the reviewed literature for our meta-analysis, landscape aesthetics, cultural heritage, biodiversity conservation or recreational values have been used to frame the valuation exercise.

Most of the studies focus on aesthetics, i.e. the WTP for changes in landscape composition and use or cultural heritage. In multifunctional European landscapes, aesthetics play an important role. It is to be expected that more complex, coherent and natural landscapes are preferred over homogeneous or simple structures (Ode et al., 2008). In this context, grasslands are important, not only as a constituting element of a heterogeneous landscape, but also as a transition between intensive croplands and forests (e.g. Hahn et al., 2018; Schaich et al., 2010). Many landscape preference studies show the positive effect of grasslands on the aesthetic value of landscapes (Hunziker et al., 2008; Junge et al., 2011; Lindemann-Matthies et al., 2011; Schirpke et al., 2016; Schüpbach et al., 2008). In addition, the traditional use of grasslands, including extensive grazing, also represents an important element of cultural heritage, especially in mountain areas (Quétier et al., 2010; Zoderer et al., 2016). Various studies have exemplified the preferences for these traditional types of land-use (Cocca et al., 2012; Marini et al., 2011; Rewitzer et al., 2017; Schenk et al., 2007). Extensive grassland also contributes to biodiversity conservation 
and habitat provision and its existence and bequest values (Bengtsson et al., 2019). A few studies address biodiversity, especially in the context of agri-environmental programs or measures (e.g. Garrod and Willis, 1995; Hanley et al., 1998; Meyerhoff et al., 2012).

Grasslands may also be used for recreational activities such as hiking, nature observation, etc., (Schirpke et al., 2018). While recreational activities often require built infrastructure, accessibility and other factors (Daniel et al., 2012), the underlying ecological conditions and land-use types, including grasslands, are also of great importance (e.g. Fuller et al., 2007; Harrison et al., 2014; Junge et al., 2009; Komossa et al., 2018). Several studies show a link between aesthetics and recreation. For example, Rewitzer et al. (2017) show that people with more frequent outdoor recreation activities tend to have a higher WTP for landscape aesthetics. Other studies explain WTP for landscape aesthetics with preferences for recreation (Drake, 1992; Tempesta and Thiene, 2014; Sagebiel et al., 2017; van Berkel and Verburg, 2014). In our meta-analysis, two studies explicitly address recreational values (Bullock and Kay, 1997; Marzetti et al., 2011) and in two further studies, the authors assess aesthetics while controlling for recreational opportunities (Garrod and Willis, 1995; Hynes and Campbell, 2011; see Table 1).

Spiritual and religious values, education, inspiration and emotional perception of a place are other potential cultural ES from grassland. However, much less research has been devoted to these aspects than to aesthetics, cultural landscapes, biodiversity and recreation (Daniel et al., 2012).

In our meta-analysis, consistency of the valued good or service is a key challenge. Subtle differences can be reconciled by including appropriate explanatory variables as regressors in the analysis (Rolfe et al., 2015). Given the low numbers of studies in some of the cultural ecosystem service categories and the fuzzy boundaries between the different services in the reviewed literature, we here focus on two broad categories in the framing of cultural ecosystem services from grassland as control variables in our regression: i) the provision of landscape aesthetics including recreational values, and ii) cultural heritage and the existence value of biodiversity from low-intensity grassland use.

The monetary valuation of cultural ES is usually based on stated preference techniques, which 'estimate measures of economic value using responses to survey questions' (Johnston et al., 2017). The collection of stated preference data can be broadly categorised into contingent valuation methods and discrete choice experiments. In contingent valuation studies, individuals are asked in surveys whether they prefer a proposed change in a public service or policy to 
(usually) the status quo (Schläpfer, 2015). Respondents state a number expressing their valuation of the corresponding service using different elicitation formats (Carson and Louviere, 2011). In discrete choice experiments, respondents are asked to make a choice between two or more alternatives in a choice set. The alternatives presented for choice are constructed by means of an experimental design that varies one or more attributes (Carson and Louviere, 2011). Attributes describe the characteristics of the service being valued, e.g. the share of grassland in a landscape. Usually, the choices presented to the respondents involve randomly assigned prices in tax rates or per-unit charges drawn from an experimental design (Schläpfer, 2015).

Other techniques are available to value cultural ES, such as hedonic pricing (e.g. Brander and Koetse, 2011) or the travel cost method (e.g. Ezebilo, 2016), but they have not been applied to grasslands. Moreover, our focus on results from discrete choice experiments and contingent valuation studies ensures commensurability of the dependent variable, which is critical to metaregression studies (Rolfe et al., 2015). In this context, a recent systematic review on discrete choice experiments implies that the results are usually similar to contingent valuation methods (Rakotonarivo et al., 2016) and elicitation formats do not affect the estimation of attribute values in ecosystem-service valuation (Petrolia et al., 2018). Thus, we combine willingness to pay estimates from contingent valuation methods and discrete choice experiments and control for methodological characteristics in the meta-regression analysis.

There is an ongoing debate regarding the usefulness and reliability of stated preferences in ES valuation (Gómez-Baggethun and Ruiz-Pérez, 2011; Schröter et al., 2014; Rakotonarivo et al., 2016). A meta-analysis does not overcome any of the potential drawbacks or methodological weaknesses of the primary studies. However, we believe that a meta-analysis offers a valuable synthesis and provides important insights into the variability of the willingness to pay for cultural ecosystem services from grasslands. Moreover, it allows structural differences in valuation studies to be tested (Bergstrom and Taylor, 2006; Rolfe et al., 2015). 


\section{Method}

We structured our methodological approach along the guidelines on economic meta-analysis as presented by Stanley et al. (2013). ${ }^{2}$

Our research question is whether and how the direction of change in grasslands, i.e. reduction in cropland, increase in forest or change in intensity levels influences the economic valuation of cultural ES from grasslands. We used the willingness to pay for grasslands to measure the economic value of cultural ES. An appropriate and consistent set of primary studies is established by focusing on studies that quantified willingness to pay per person or per household and year for grasslands in Europe using either contingent valuation methods or discrete choice experiments. The reported estimates were converted into Euros per person per year using the exchange rate of the year of the study. In addition, we adjusted estimates from different countries and years to account for purchasing power parities (Eurostat, 2019). Signs were switched in studies that value a reduction in grasslands. Thus, if surveys showed a positive willingness to pay for a change from grassland to cropland, this implies that people would have to be compensated with the same amount for a change from cropland to grassland.

The methods used in the studies collected to assess the willingness to pay for grassland do not allow further standardisation of the effect size, e.g. the willingness to pay per person or household per ha of grassland. In particular, most of the studies we reviewed assessed willingness to pay using pictures of landscapes or asked for a choice in a case study region without documentation of the effective spatial extent of the corresponding change. Thus, our analysis does not provide a direct basis for benefit transfer. However, it investigates the effect of the type of change. It controls for the cultural ecosystem service, methodological and case study specific variables and thus offers suggestions for improvements in the design of cultural ES grassland studies and opens new perspectives for the transfer of grassland benefits (Nelson and Kennedy, 2009).

\subsection{Data collection}

Our search for appropriate primary studies reporting on willingness to pay estimates for cultural ecosystem services for grasslands in Europe involved three steps. First, we checked the references cited in existing reviews about landscape valuations in Europe (i.e. Ciaian and Gomez y Paloma, 2011; van Zanten et al., 2014) and in mountain regions (Grêt-Regamey et al., 2008) to

\footnotetext{
${ }^{2}$ We also included a description of our meta-analysis based on the PRISMA-P checklist by Moher et al. (2015) in online Appendix D.
} 
see whether they included grassland as an explicit feature or element in the valuation exercise. We found 19 studies that corresponded to our search criteria, i.e. referring to grasslands, Europe and stated preference techniques. Second, we explored the Environmental Valuation Reference Inventory database for contingent valuation studies that included grassland (EVRI 2018). There were 13 studies, 6 of which had not been reported in the existing reviews. Third, we looked through databases including Scopus, Web of Science and Google Scholar for studies that included grassland AND economic valuation. In this third step, we were able to locate eight additional studies. In total, we identified 33 publications (Table 1) that corresponded to our search criteria, with 88 reported willingness to pay estimates. Study 5 (Table 1) presented the same estimates from an earlier manuscript considered in our review and was excluded from our dataset. We also excluded six observations in which the willingness to pay was presented in relation to the area and not with respect to persons or households (from Studies 16, 21 and 31). In addition, we had to exclude one observation because the study reported predicted values rather than the original estimates. We restricted our investigation to i) peer reviewed publications, ii) conference proceedings, and iii) $\mathrm{PhD}$ theses in English, German and French. Our final dataset thus included 32 studies and 79 observations (see Appendix A, online, for a full presentation of the data and sources). Note that we were not able to collect the standard errors for all the estimates from the original studies, but could retrieve sample sizes for all studies. 
Table 1: List of reviewed willingness to pay studies valuing grassland

\begin{tabular}{|c|c|c|c|}
\hline & Author(s) and year of publication & Title & Journal \\
\hline 1 & Willis and Garrod (1992) & Assessing the value of future landscapes & Landscape and Urban Planning \\
\hline 2 & Drake (1992) & The non-market value of the Swedish agricultural landscape & $\begin{array}{l}\text { European review of agricultural } \\
\text { economics }\end{array}$ \\
\hline 3 & Garrod and Willis (1995) & Valuing the benefits of the south downs environmentally sensitive area & Journal of Agricultural Economics \\
\hline 4 & Bullock and Kay (1997) & $\begin{array}{l}\text { Preservation and Change in the Upland Landscape: The Public Benefits of Graz- } \\
\text { ing Management }\end{array}$ & $\begin{array}{l}\text { Journal of Environmental Planning } \\
\text { and Management }\end{array}$ \\
\hline 5 & Hanley, MacMillan et al., (1998) & $\begin{array}{l}\text { Contingent Valuation Versus Choice Experiments: Estimating the Benefits of En- } \\
\text { vironmentally Sensitive Areas in Scotland }\end{array}$ & Journal of Agricultural Economics \\
\hline 6 & Křůmalová (2002) & $\begin{array}{l}\text { Evaluation of chosen benefits on environment and landscape coming from } \\
\text { Czech agriculture }\end{array}$ & Agricultural Economics (CZ) \\
\hline 7 & Schmitz, Schmitz et al., (2003) & Valuation of landscape functions using choice experiments & Agrarwirtschaft \\
\hline 8 & Schmitt, Schläpfer et al., (2005) & $\begin{array}{l}\text { Bewertung von Landschaftsveränderungen im Schweizer Mittelland aus Sicht } \\
\text { der Bevölkerung }\end{array}$ & Report \\
\hline 9 & Baumgart (2005) & $\begin{array}{l}\text { Bewertung landschaftsrelevanter Projekte im Schweizer Alpenraum - Die Me- } \\
\text { thode der Diskrete-Choice-Experimente }\end{array}$ & PhD Thesis \\
\hline 10 & Schmitz (2006) & $\begin{array}{l}\text { Die Bewertung von Multifunktionalität der Landschaft mit diskreten Choice Ex- } \\
\text { perimenten }\end{array}$ & PhD Thesis \\
\hline 11 & Campbell (2007) & $\begin{array}{l}\text { Willingness to Pay for Rural Landscape Improvements: Combining Mixed Logit } \\
\text { and Random-Effects Models }\end{array}$ & Journal of Agricultural Economics \\
\hline 12 & Moran, McVittie et al., (2007) & $\begin{array}{l}\text { Quantifying public preferences for agri-environmental policy in Scotland: A } \\
\text { comparison of methods }\end{array}$ & Ecological Economics \\
\hline 13 & Schläpfer and Schmitt (2007) & Anchors, endorsements, and preferences: A field experiment & Resource and Energy Economics \\
\hline 14 & Campbell, Hutchinson et al., (2009) & $\begin{array}{l}\text { Using choice experiments to explore the spatial distribution of willingness to } \\
\text { pay for rural landscape improvements }\end{array}$ & Environment and Planning $\mathrm{A}$ \\
\hline 15 & Borresch, Maas et al., (2009) & $\begin{array}{l}\text { Modelling the value of a multifunctional landscape - A discrete choice experi- } \\
\text { ment }\end{array}$ & $\begin{array}{l}\text { Presentation at International Asso- } \\
\text { ciation of Agricultural Economists } \\
\text { Conference }\end{array}$ \\
\hline 16 & Hasund, Kataria et al., (2011) & $\begin{array}{l}\text { Valuing public goods of the agricultural landscape: a choice experiment using } \\
\text { reference points to capture observable heterogeneity }\end{array}$ & $\begin{array}{l}\text { Journal of Environmental Planning } \\
\text { and Management }\end{array}$ \\
\hline 17 & Howley, Hynes et al., (2010) & $\begin{array}{l}\text { The citizen versus consumer distinction: An exploration of individuals prefer- } \\
\text { ences in Contingent Valuation studies }\end{array}$ & Ecological Economics \\
\hline 18 & Yadav, van Rensburg et al., (2010) & $\begin{array}{l}\text { Comparing the conventional Stated Preference Valuation Technique with a Pre- } \\
\text { diction Approach }\end{array}$ & $\begin{array}{l}\text { The 84th Annual Conference of } \\
\text { the Agricultural Economics Society }\end{array}$ \\
\hline
\end{tabular}




\begin{tabular}{|c|c|c|c|}
\hline 19 & Hynes and Campbell (2011) & $\begin{array}{l}\text { Estimating the welfare impacts of agricultural landscape change in Ireland: a } \\
\text { choice experiment approach }\end{array}$ & $\begin{array}{l}\text { Journal of Environmental Planning } \\
\text { and Management }\end{array}$ \\
\hline 20 & Hynes, Campbell et al., (2011) & $\begin{array}{l}\text { A Holistic vs. an Attribute-based Approach to Agri-Environmental Policy Valua- } \\
\text { tion: Do Welfare Estimates Differ? }\end{array}$ & Journal of Agricultural Economics \\
\hline 21 & Huber, Hunziker et al., (2011) & $\begin{array}{l}\text { Valuation of agricultural land-use scenarios with choice experiments: a political } \\
\text { market share approach }\end{array}$ & $\begin{array}{l}\text { Journal of Environmental Planning } \\
\text { and Management }\end{array}$ \\
\hline 22 & Marzetti, Disegna et al., (2011) & $\begin{array}{l}\text { Conservation and recreational values from semi-natural grasslands for visitors } \\
\text { to two Italian parks }\end{array}$ & $\begin{array}{l}\text { Journal of Environmental Planning } \\
\text { and Management }\end{array}$ \\
\hline 23 & Meyerhoff, Angeli et al., (2012) & $\begin{array}{l}\text { Valuing the benefits of implementing a national strategy on biological diversity } \\
\text { - The case of Germany }\end{array}$ & Environmental Science \& Policy \\
\hline 24 & van Berkel and Verburg (2014) & $\begin{array}{l}\text { Spatial qualification and valuation of cultural ecosystem services in an agricul- } \\
\text { tural landscape }\end{array}$ & Ecological Indicators \\
\hline 25 & Christie and Rayment (2012) & $\begin{array}{l}\text { An economic assessment of the ecosystem service benefits derived from the } \\
\text { SSSi biodiversity conservation policy in England and Wales }\end{array}$ & Ecosystem Services \\
\hline 26 & Bernués, Rodríguez-Ortega et al., (2014) & $\begin{array}{l}\text { Socio-Cultural and Economic Valuation of Ecosystem Services Provided by Med- } \\
\text { iterranean Mountain Agroecosystems }\end{array}$ & PLOS ONE \\
\hline 27 & Wüstemann, Meyerhoff et al., (2014) & $\begin{array}{l}\text { Financial costs and benefits of a program of measures to implement a National } \\
\text { Strategy on Biological Diversity in Germany }\end{array}$ & Land Use Policy \\
\hline 28 & Dallimer, Jacobsen et al., (2015) & $\begin{array}{l}\text { Patriotic Values for Public Goods: Transnational Trade-Offs for Biodiversity and } \\
\text { Ecosystem Services? }\end{array}$ & BioScience \\
\hline 29 & Tempesta and Thiene (2014) & $\begin{array}{l}\text { The willingness to pay for the conservation of mountain landscape in Cortina } \\
\text { D'Ampezzo (Italy) }\end{array}$ & Working paper \\
\hline 30 & Tinch, Colombo et al., (2015) & $\begin{array}{l}\text { The Impacts of Elicitation Context on Stated Preferences for Agricultural Land- } \\
\text { scapes }\end{array}$ & Journal of Agricultural Economics \\
\hline 31 & Rewitzer, Huber et al., (2017) & $\begin{array}{l}\text { Economic valuation of cultural ecosystem service changes to a landscape in the } \\
\text { Swiss Alps }\end{array}$ & Ecosystem Services \\
\hline 32 & Sagebiel, Glenk et al., (2017) & Spatially explicit demand for afforestation & Forest Policy and Economics \\
\hline 33 & Mazzocchi and Sali (2018) & $\begin{array}{l}\text { Assessing the value of pastoral farming in the Alps using choice experiments: } \\
\text { evidence for public policies and management }\end{array}$ & $\begin{array}{l}\text { Journal of Environmental Planning } \\
\text { and Management }\end{array}$ \\
\hline
\end{tabular}




\subsection{Data description}

The independent variables were coded in three categories i) direction of grassland change and cultural ES framing, ii) methodological design, and iii) case study characteristics (Table 2).

First, categorical variables were used to categorise reported willingness to pay estimates per person or per household per year according to whether they addressed i) grassland abandonment, ii) less-intensive grassland use, or iii) a switch from cropland to grassland. A dummy variable was used for each of the three categories to assign the assessed grassland ES with respect to their framing, i.e. whether the valuation exercise of the cultural ES referred to landscape aspects (aesthetics) and recreational values, or to cultural heritage and biodiversity conservation.

Second, we collected the methodological characteristics of the studies. The studies were coded according to type to allow us to control for a systematic difference between contingent valuation methods and discrete choice experiments. In addition, we controlled for different elicitation formats, i.e. the way the grassland change was presented and the willingness to pay question was asked. To this end, we checked whether the study used a so-called 'matching strategy', i.e. open-ended questions and payment card formats or a discrete choice setting (Carson and Louviere, 2011). If the question was based on an open-ended or payment card format, we also recorded whether the authors framed the question showing two alternatives, i.e. in a dichotomous choice or referendum format. Furthermore, we coded the studies according to whether a single or a sequence of questions was asked.

We also assessed the presentation of the changes in cultural ES and registered whether the changes were presented in pictures or only by means of a descriptive text. Moreover, we noted whether the proposed change in a public service was presented in marginal units, i.e. in a small number of hectares or species, or in absolute changes, i.e. in changes on manipulated photos or pictures of the entire landscape. Different elicitation formats were used to test the sensitivity of our results with respect to sub-groups of our data sample.

Third, we used case study specific variables. We controlled for factors in the execution of the survey, i.e. whether data were collected via mail survey or in face-to-face interviews and whether the study was based on a probability or non-probability sampling. In addition, we included the year of the study and number of participants and also coded who precisely was surveyed, i.e. local residents, visitors and tourists, or the general public. We used the gross domestic product (GDP) and the expenditure per capita in purchasing power standards (PPS) taken from the eurostat database (Eurostat, 2019) to account for differences in wealth and standard of 
living. In addition, the studies were classified with respect to their institutional state, i.e. if the region comprised a natural park or an environmentally sensitive area.

Various spatial aspects of the studies were likewise examined. We coded whether a study was performed on a national scale or within a specific case study region. In the latter case, we recorded the size of the region involved. Since many of the studies were performed in the UK and Ireland, we controlled for potential regional biases. We also checked the policy framing of the valuation exercise, i.e. if it directly included an agri-environmental scheme or not. Finally, we identified the landscape type in the valuation exercise, i.e. whether the study focused specifically on mountain (or upland) regions.

Our data were collected and coded by three researchers who discussed differences in the independent assessments and jointly agreed on the final dataset. 
Table 2: List of variables encoded from the literature review

\begin{tabular}{|c|c|c|c|c|c|c|}
\hline & Variable & Description & \multicolumn{2}{|l|}{ Coding } & Mean & $\begin{array}{l}\text { Standard } \\
\text { deviation }\end{array}$ \\
\hline & & Depended variable & & & & \\
\hline & WTP & $\begin{array}{l}\text { Expressed WTP in Euro (using the exchange rate } \\
\text { in the year of the study and corrected for pur- } \\
\text { chasing power parity) }\end{array}$ & \multicolumn{2}{|c|}{ Euro per person or household per year } & 38.46 & 53.43 \\
\hline & & Independent variables & & & & \\
\hline \multirow[t]{6}{*}{ Framing CES } & \multirow[t]{2}{*}{ TypChange I } & \multirow[t]{2}{*}{$\begin{array}{l}\text { Direction of change: from intensive to less inten- } \\
\text { sive grassland use }\end{array}$} & $\begin{array}{l}\text { Abandonment \& cropland } \\
(0)\end{array}$ & Less-intensive (1) & & \\
\hline & & & 37 & 42 & & \\
\hline & \multirow[t]{2}{*}{ TypChange II } & \multirow[t]{2}{*}{ Direction of change: from cropland to grassland } & $\begin{array}{l}\text { Abandonment \& less inten- } \\
\text { sive (0) }\end{array}$ & $\begin{array}{l}\text { Cropland to grassland } \\
\text { (1) }\end{array}$ & & \\
\hline & & & 69 & 10 & & \\
\hline & \multirow[t]{2}{*}{ TypES } & \multirow[t]{2}{*}{ Framing of the ES subject to valuation } & Landscape aesthetics (0) & $\begin{array}{l}\text { Cultural heritage / biodiver- } \\
\text { sity (1) }\end{array}$ & & \\
\hline & & & 48 & 31 & & \\
\hline \multirow{17}{*}{$\begin{array}{l}\text { Methodologi- } \\
\text { cal design }\end{array}$} & \multirow[t]{2}{*}{ Method } & \multirow[t]{2}{*}{ Underlying method } & CVM (0) & DCE (1) & & \\
\hline & & & 32 & 47 & & \\
\hline & \multirow[t]{2}{*}{ Marginal } & \multirow{2}{*}{$\begin{array}{l}\text { Representation of change in countable, small } \\
\text { units (e.g. number of species) or rather absolute } \\
\text { changes (e.g., change in grassland on pictures) }\end{array}$} & Marginal changes $(0)$ & Absolute change (1) & & \\
\hline & & & 29 & 50 & & \\
\hline & \multirow[t]{2}{*}{ Open ended } & \multirow[t]{2}{*}{ Open ended format of WTP question } & No $(0)$ & Yes (1) & & \\
\hline & & & 62 & 17 & & \\
\hline & \multirow[t]{2}{*}{ Payment card } & \multirow{2}{*}{$\begin{array}{l}\text { Use of payment card as a payment vehicle in WTP } \\
\text { question }\end{array}$} & No $(0)$ & Yes (1) & & \\
\hline & & & 64 & 15 & & \\
\hline & \multirow[t]{2}{*}{ Dichotomous } & \multirow{2}{*}{$\begin{array}{l}\text { Choice between two landscapes before either } \\
\text { open ended question or payment card format }\end{array}$} & No $(0)$ & Yes (1) & & \\
\hline & & & 64 & 13 & & \\
\hline & \multirow[t]{2}{*}{ Sequential } & \multirow[t]{2}{*}{ Single or a sequence of questions } & No $(0)$ & Yes (1) & & \\
\hline & & & 25 & 54 & & \\
\hline & \multirow[t]{2}{*}{ MNC } & \multirow[t]{2}{*}{ Multinomincal choice setting } & No $(0)$ & Yes (1) & & \\
\hline & & & 32 & 47 & & \\
\hline & \multirow[t]{3}{*}{ Text } & \multirow{3}{*}{$\begin{array}{l}\text { Illustration of WTP with pictures, symbols or only } \\
\text { with text }\end{array}$} & Text (0) & Symbols or pictures (1) & & \\
\hline & & & 12 & 67 & & \\
\hline & & & 12 & 67 & & \\
\hline
\end{tabular}




\begin{tabular}{|c|c|c|c|c|c|c|}
\hline \multirow[t]{25}{*}{$\begin{array}{l}\text { Case study } \\
\text { related }\end{array}$} & Year & $\begin{array}{l}\text { Year in which the study took place (if not re- } \\
\text { ported, year of publication) }\end{array}$ & $\begin{array}{l}\text { Yearly time steps } 1986=1 \\
\qquad 2015=28\end{array}$ & & & \\
\hline & \multirow[t]{2}{*}{ Person } & \multirow[t]{2}{*}{ WTP on individual or on household level } & Individual $(0)$ & Household (1) & & \\
\hline & & & 42 & 37 & & \\
\hline & \multirow[t]{2}{*}{ Int } & \multirow{2}{*}{$\begin{array}{l}\text { Collection of results using face-to-face interviews } \\
\text { or any other type of survey e.g., per mail or online }\end{array}$} & Survey $(0)$ & Interview (1) & & \\
\hline & & & 33 & 46 & & \\
\hline & \multirow[t]{2}{*}{ Sampling } & \multirow{2}{*}{$\begin{array}{l}\text { Whether the data was based on a probability or } \\
\text { non-probability sampling }\end{array}$} & Non-probability sampling (0) & Probability sampling (1) & & \\
\hline & & & 12 & 67 & & \\
\hline & Participants & Number of participants who expressed their WTP & \multicolumn{2}{|l|}{ Number } & 456 & 395 \\
\hline & \multirow[t]{2}{*}{ Visitor } & \multirow[t]{2}{*}{$\begin{array}{l}\text { Characterization of the participants with respect } \\
\text { to their origin: Visitors }\end{array}$} & $\begin{array}{l}\text { Local residents \& general } \\
\text { public (0) }\end{array}$ & Visitors or tourists (1) & & \\
\hline & & & 68 & 11 & & \\
\hline & \multirow[t]{2}{*}{ Public } & \multirow{2}{*}{$\begin{array}{l}\text { Characterization of the participants with respect } \\
\text { to their origin: General public }\end{array}$} & Local residents \& visitors (0) & General public (1) & & \\
\hline & & & 17 & 62 & & \\
\hline & \multirow[t]{2}{*}{ Program } & \multirow[t]{2}{*}{ Consideration of a specific policy program } & No $(0)$ & Yes (1) & & \\
\hline & & & 59 & 20 & & \\
\hline & \multirow[t]{2}{*}{ Region } & \multirow{2}{*}{$\begin{array}{l}\text { Did the study specifically address a mountain re- } \\
\text { gion or not (including upland regions in the UK)? }\end{array}$} & No $(0)$ & Yes (1) & & \\
\hline & & & 47 & 32 & & \\
\hline & \multirow[t]{2}{*}{ Park } & \multirow{2}{*}{$\begin{array}{l}\text { Did the survey / interviews take place in a park or } \\
\text { an area in the habitat directive? }\end{array}$} & Yes (0) & No (1) & & \\
\hline & & & 40 & 39 & & \\
\hline & \multirow[t]{2}{*}{ Country } & \multirow[t]{2}{*}{ Study in the UK or Ireland? } & Yes (0) & No (1) & & \\
\hline & & & 28 & 51 & & \\
\hline & \multirow[t]{2}{*}{ Nation } & \multirow[t]{2}{*}{ Case study or national level? } & Case study (0) & National (1) & & \\
\hline & & & 53 & 26 & & \\
\hline & Size & $\begin{array}{l}\text { Size of the case study area (if not on a national } \\
\text { level) }\end{array}$ & \multicolumn{2}{|l|}{$\mathrm{Km}^{2}$} & 919 & 778 \\
\hline & GDP & GDP in the year of the study & \multicolumn{2}{|l|}{ Euro } & $33^{\prime} 228$ & $11^{\prime} 673$ \\
\hline & $\begin{array}{l}\text { Living stand- } \\
\text { ard }\end{array}$ & $\begin{array}{l}\text { Real expenditure per capita in PPS (EU } 28 \text { in } 2010 \\
=100 \text { ) }\end{array}$ & \multicolumn{2}{|l|}{$\%$} & 119.8 & 23.78 \\
\hline
\end{tabular}




\subsection{Econometric analysis}

We use regression analysis to explain the variation in reported willingness to pay estimates. More specifically, we aimed to identify the effects of the type of grassland change and cultural ES, methodological variables and case study related variables. We estimated several specifications of the following regression model:

$$
W T P_{i}=\beta_{0}+\beta_{k} X_{k i}+\epsilon_{i}
$$

where $W T P_{i}$ with $i=1 \ldots 79$ represents the identified willingness to pay estimates from our data collection, $X_{k}$ is a vector containing $k$ variables related to the framing, study design and case study specifics used to estimate the willingness to pay (WTP) for grassland, and $\epsilon_{i}$ is an error term. We used the MM-estimator. This is a robust regression technique that allows the potential impacts of outliers to be reduced while maintaining high efficiency of the estimator (Finger, 2010). Moreover, we applied multi-way clustering based on Cameron et al. (2011) to adjust standard errors for variations within clusters, i.e. to account for possible multiple estimates reported by the same research article. This accommodates within-study dependence.

Collinearity problems were identified by analysing correlations between variables. The variance inflation factors of the selected model were estimated to test for any remaining potential problems of multicollinearity (Fox and Monette, 1992). Variables with potential multicollinearity problems were dropped (see Appendix B, online, for a full explanation of variable choice and estimation strategy). Finally, a subsample sensitivity analysis was performed to ascertain whether our regression is affected by the exclusion of the estimates for a switch from cropland to grassland (see Appendix B, online, for a full presentation of regression diagnostics and sensitivity analysis).

Publication selection bias in meta-analysis refers to the fact that statistically significant results are essentially more likely to be published than those without any statistical significance (Hirsch, 2018; Stanley, 2005). Since standard errors are not available for all the studies included in our analysis, we used the sample size to measure the precision of estimates (Sterne et al., 2000 and Macaskill et al., 2001). To be specific, we tested for publication selection bias by regressing reported values to the square root of the sample size in the corresponding study (funnel asymmetry test). We found that the sample size had no effect on the willingness to pay. This implies that observed effects vary randomly around the 'true' effect, i.e. the mean of the $10 \%$ of the studies with the highest square root of the sample size and that there is no publication bias in our study selection (see analysis in Appendix B, online). Thus, we assign each study 
equal weight in our meta-regression. The analysis was conducted using $\mathrm{R}$ (code available in Appendix C, online).

\section{Results}

\subsection{Willingness to pay for grassland}

Figure 1 shows estimates for grassland ecosystem services published over the period 19902018 , by date of publication. The average willingness to pay indicated by these estimates is 38 Euros (Median 32 Euros) with a range from -112 to +236 Euros. The smallest positive willingness to pay (0.8 Euros for grassland in Czech Republic) is almost 300 times smaller than the highest estimate (236 Euros for grassland in Swiss mountains). This kind of variation across studies is typical for valuation studies and an important motivation for meta-analysis (Rolfe et al., 2015). In addition, we see that the number of choice experiment studies increased compared to contingent valuation methods studies over our data period (see also Mahieu et al., 2017). The descriptive analysis also showed that willingness to pay for grassland ES was higher for a reduction in grassland intensity levels in a mountain region and lower for a switch from cropland to grassland in other regions (Figure 2). These differences in the willingness to pay for the different types of grassland changes is also present in all the sub-samples analysed (Appendix Figure B4, online).

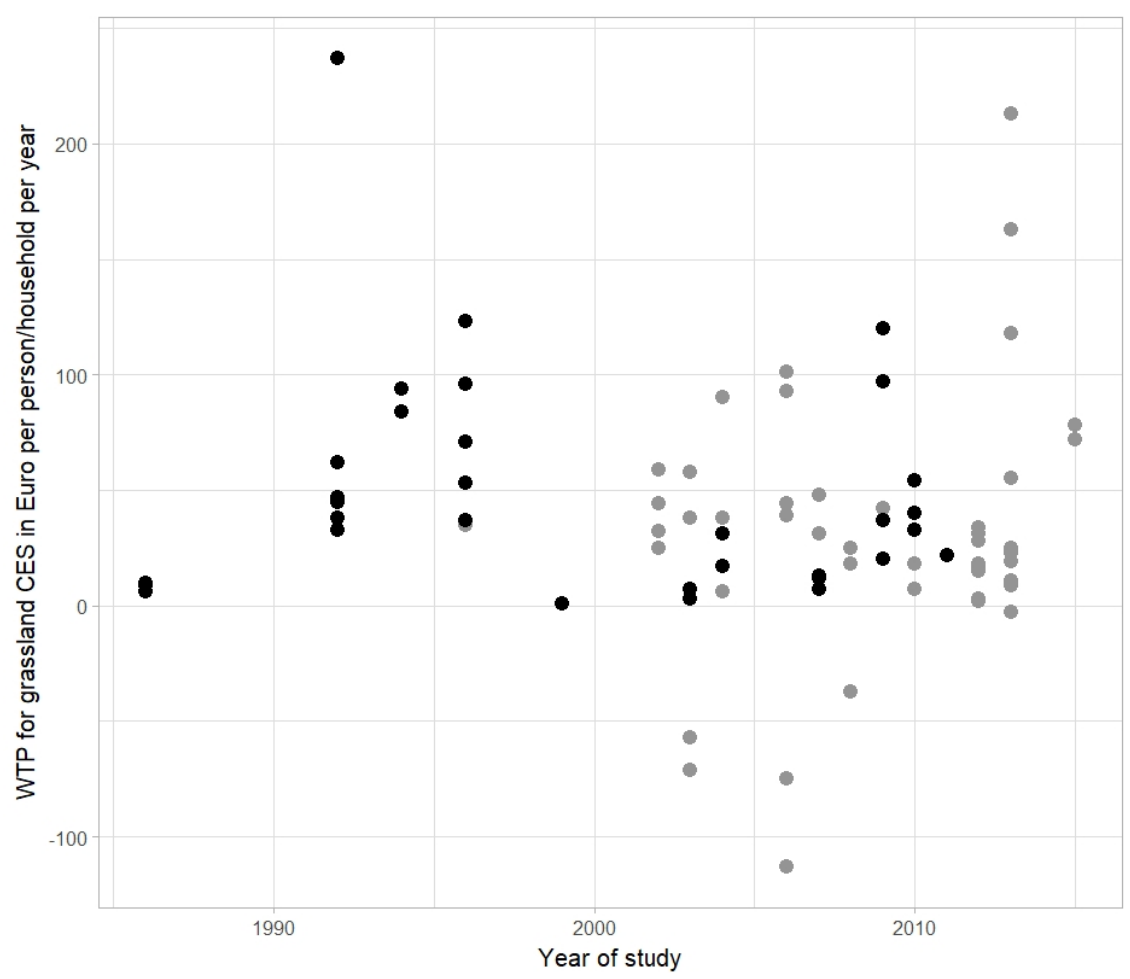

Figure 1. Willingness to pay (WTP) for cultural ecosystem services (CES) from grasslands in studies using a contingent valuation method (black) or a discrete choice experiment (grey) published over the period $1990-2018$. Note: The study by Drake was conducted in 1986 and published in 1992. 


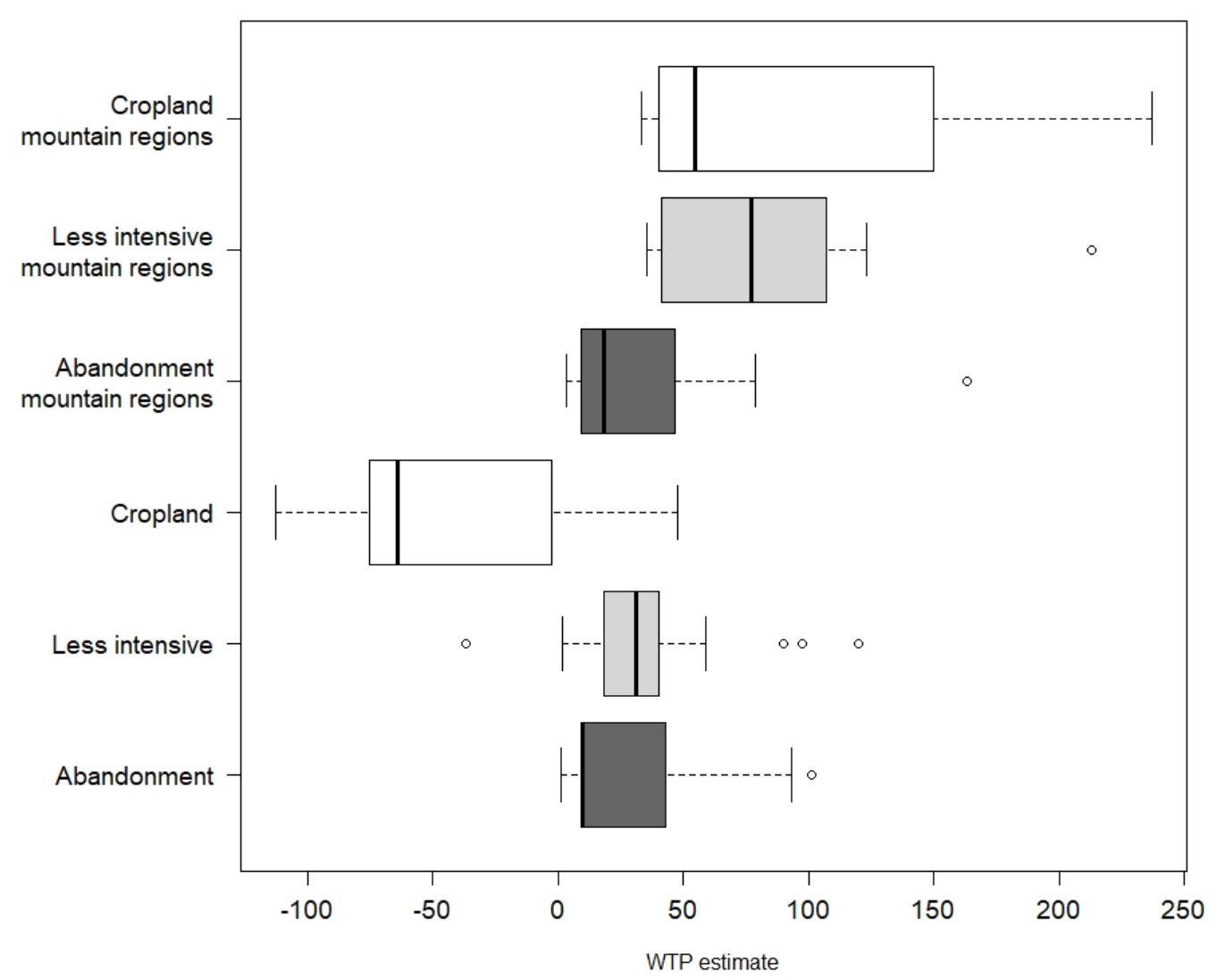

Figure 2. Box plots of reported willingness to pay estimates in Euro per person or household per year for abandonment (grey), less-intensive grassland use (light grey) and cropland (white) across mountain and lowland regions. Box plots summarize the 79 observations collected in our review. The black line represents mean WTP. Boxes include the second and third quantile of willingness to pay estimates. The whiskers show the 10th-90th percentiles. Outliers above and below the whiskers are drawn as individual points.

\subsection{Estimation results}

Table 3 shows the estimation results for the main model and three subsets of the data. The willingness to pay per person and year varies significantly between changes from cropland to grassland as compared to abandonment or less-intensive grassland use when the full dataset (Model 1) is applied. In addition, interaction effects between regions and the type of change are also significant. More specifically, if a switch from cropland to grassland is evaluated in mountain regions, the willingness to pay is higher compared to such changes in the lowlands. In mountain regions, a change to less-intensive grassland use also generates higher willingness to pay. These variables remain significant in all the specifications of the econometric estimation. Thus, our results provide a robust indication that the direction of change clearly influences the willingness to pay for grassland ( $c f$. sensitivity analysis in Appendix B, online). In addition, the willingness to pay also increases by approximately 20 Euros if the grassland cultural ES is framed in the context of cultural heritage rather than landscape per se. 
Table 3: Meta-regression of willingness to pay for cultural services in European grassland

\begin{tabular}{|c|c|c|c|c|c|c|c|c|c|c|c|c|}
\hline \multirow[t]{2}{*}{$\begin{array}{l}\text { Dependent variable: WTP corrected } \\
\text { for purchasing power parity per } \\
\text { country and year (in Euro) }\end{array}$} & \multicolumn{3}{|c|}{$\begin{array}{l}\text { Model 1: Full dataset, account- } \\
\text { ing for abandonment - less in- } \\
\text { tensive - cropland }\end{array}$} & \multicolumn{3}{|c|}{$\begin{array}{l}\text { Model 2: Sensitivity analysis } \\
\text { using only those observations } \\
\text { that address abandonment } \\
\text { and less-intensive grassland } \\
\text { use }\end{array}$} & \multicolumn{3}{|c|}{$\begin{array}{l}\text { Model 3: Sensitivity analysis in- } \\
\text { cluding the size of the study } \\
\text { region as explanatory variable } \\
\text { and excluding studies on na- } \\
\text { tional level. }\end{array}$} & \multicolumn{3}{|c|}{$\begin{array}{l}\text { Model 4: Sensitivity analysis } \\
\text { without observations based on } \\
\text { direct open ended questions }\end{array}$} \\
\hline & Estimate & $\operatorname{Pr}(>|t|)^{\$}$ & & Estimate & $\operatorname{Pr}(>|t|)^{\$}$ & & Estimate & $\operatorname{Pr}(>|t|)^{\$}$ & & Estimate & $\operatorname{Pr}(>|t|)^{\$}$ & \\
\hline Intercept & -21.13 & 0.405 & & -7.06 & 0.765 & & -17.07 & 0.657 & & -1.51 & 0.958 & \\
\hline Abandonment - Less intensive & -14.61 & 0.059 &. & -13.45 & 0.049 & $*$ & -5.71 & 0.684 & & -19.75 & 0.067 & . \\
\hline Region & -46.04 & 0.000 & $* * *$ & -49.14 & 0.000 & $* * *$ & -50.57 & 0.004 & $* *$ & -54.24 & 0.004 & $* *$ \\
\hline Abandonment - Cropland & -116.61 & 0.000 & $* * *$ & & & & -111.20 & 0.000 & $* * *$ & -125.02 & 0.000 & $* * *$ \\
\hline Framing of CES & 13.70 & 0.083 &. & 17.96 & 0.038 & $*$ & 15.67 & 0.003 & $* *$ & 13.84 & 0.098 & \\
\hline Marginal & 42.41 & 0.000 & $* * *$ & 46.03 & 0.000 & $* * *$ & 47.17 & 0.000 & $* * *$ & 37.59 & 0.001 & $* * *$ \\
\hline Dichotomous choice setting & 48.89 & 0.000 & $* * *$ & 47.59 & 0.000 & $* * *$ & 44.22 & 0.017 & $*$ & 56.97 & 0.000 & $* * *$ \\
\hline Open ended & -4.35 & 0.662 & & -9.81 & 0.332 & & -18.94 & 0.019 & $*$ & -0.94 & 0.964 & \\
\hline Person / household & -2.45 & 0.645 & & 0.47 & 0.929 & & -4.39 & 0.640 & & -0.04 & 0.994 & \\
\hline Multinomial choice setting & 36.98 & 0.021 & $*$ & 29.42 & 0.061 & . & 31.73 & 0.012 & $*$ & 34.38 & 0.031 & $*$ \\
\hline Interview / survey & -10.20 & 0.095 & . & -11.62 & 0.061 & . & -3.81 & 0.760 & & -15.42 & 0.099 & . \\
\hline Text / picture & -19.11 & 0.007 & $* *$ & -20.69 & 0.001 & $* *$ & -27.93 & 0.080 & . & -18.64 & 0.036 & $*$ \\
\hline Year & 1.35 & 0.005 & $* *$ & 1.47 & 0.000 & $* * *$ & 1.42 & 0.007 & $* *$ & 1.78 & 0.022 & $*$ \\
\hline Number of participants & -0.03 & 0.006 & $* *$ & -0.03 & 0.003 & $* *$ & -0.03 & 0.122 & & -0.04 & 0.002 & $* *$ \\
\hline Local - visitors, tourists & -15.75 & 0.024 & $*$ & -16.52 & 0.040 & $*$ & -12.00 & 0.149 & & -25.39 & 0.163 & \\
\hline Local - general public & -4.40 & 0.580 & & -8.50 & 0.302 & & -7.95 & 0.550 & & -16.94 & 0.200 & \\
\hline Agri-environmental program & 27.43 & 0.200 & & 15.21 & 0.471 & & & & & 34.07 & 0.034 & $*$ \\
\hline Park & 7.08 & 0.283 & & 8.33 & 0.187 & & 10.97 & 0.103 & & 1.35 & 0.870 & \\
\hline Expenditure & 0.21 & 0.103 & & 0.14 & 0.254 & & 0.20 & 0.063 & . & 0.22 & 0.082 & . \\
\hline Size & & & & & & & 0.01 & 0.193 & & & & \\
\hline Less intensive : Mountain & 48.28 & 0.011 & $*$ & 55.03 & 0.001 & $* * *$ & 58.55 & 0.006 & $* *$ & 47.66127 & 0.052665 & . \\
\hline Cropland : Mountain & 110.05 & 0.000 & $* * *$ & & & & 137.60 & 0.000 & $* * *$ & & & \\
\hline$R^{2}$ (adj.) & 0.79 & & & 0.72 & & & 0.79 & & & 0.79 & & \\
\hline
\end{tabular}

Signif. codes: ${ }^{* * * \prime} 0.001^{\prime * * \prime} 0.01^{\prime * \prime} 0.05 !^{\prime \prime} 0.1$; \$Error terms clustered by study. 
A sensitivity analysis using only those observations that address abandonment and less-intensive grassland use $(n=69)$ shows that the same variables remain significant (Table 3, Model 2). Willingness to pay for less-intensive grassland use in mountain regions is still significantly higher compared to abandonment and less-intensive grassland use in the lowlands. We also controlled for the size of the case study region in an additional subsample. Again, the estimates with respect to type of change, region and cultural ES framing did not differ significantly (Table 3, Model 3). In each case, the direction of change and the type of cultural ES have a significant impact on the willingness to pay for grasslands. Finally, this result is also confirmed even when observations with an open-ended question (Table 3, Model 4) are not considered.

Our results also demonstrate the relevance of methodological and study related variables when explaining the variation in peoples' willingness to pay for grassland ES. In particular, willingness to pay increases when the changes are presented as absolute rather than marginal changes. Moreover, studies that required participants to respond to a dichotomous choice or a referendum format led to higher estimates. In the sub-dataset without changes from crop to grassland (Model 2), willingness to pay declined when surveys were carried out instead of interviews and pictures were presented instead of texts only. Multinomial choice settings generally resulted in higher estimates. Other methodological variables did not affect willingness to pay in our analysis. We re-ran the econometric analysis considering contingent valuation methods and discrete choice experiments studies separately as a robustness check. The results reveal that the direction of grassland change, i.e. grassland abandonment, reduction in cropland or change in intensity levels was always a significant variable despite the lower observations in the split sample. However, the framing of cultural ES and the region, i.e. mountain or not, was not significant in contingent valuation methods.

The year of the survey was a significant variable in relation to the study. However, it was strongly correlated with GDP (see Appendix Table B1, online, for correlation analysis and calculation of variance inflation factors). We excluded GDP from the regression as it was also correlated with expenditure. Thus, the annual increase in willingness to pay can, to some extent, be explained by the increase of GDP in all countries during the period analysed. In general, visitors exhibited a lower willingness to pay than the local population and residents. However, this effect is not significant in all the subsamples. Estimates increased when framed in the context of an agri-environmental measure if those studies using an open-ended question were excluded. Finally, the size of the case study region also increases willingness to pay in our subsample. Other independent variables related to the case study were not significant in our metaregression. 


\section{Discussion and Conclusion}

Grasslands provide a wide range of ES with various benefits for society. We provide a metaanalysis on the monetary valuation of cultural ES of grasslands in Europe using data from 32 studies that provide a total of 79 estimates on the willingness to pay. Our results show a positive and significant willingness to pay for cultural ecosystem services of grasslands. However, we find that the monetary valuation exercise must be framed in relation to the direction of grassland change. A switch from cropland to grassland reduces willingness to pay by 90 Euros, while an increase in less-intensive land-use in mountain regions raises willingness to pay by 53 Euros. We find that willingness to pay also increases by approximately 20 Euros if the grassland cultural ES is framed in the context of cultural heritage or biodiversity rather than landscape aesthetics or recreational values. Our results open the way to an improved perception of grasslands in cost-benefit analysis and, ultimately, support the design and evaluation of conservation or agri-environmental measures (Pascual et al., 2010; Richardson et al., 2015).

In addition, our meta-analysis shows the importance of methodological related choices in stated preference studies. The results imply that surveys including dichotomous or multinomial choices increase peoples' willingness to pay for cultural ecosystem services from grasslands. This finding is in line with similar meta-analysis of landscape values (Ciaian and Gomez y Paloma, 2011), recreational values (e.g. De Salvo and Signorello, 2015; Schägner et al., 2018), biodiversity conservation (Jacobsen et al., 2009) or values of threatened species (e.g. Richardson and Loomis, 2009; Subroy et al., 2019). In addition, willingness to pay is higher when the survey participants valued a change in the landscape compared to a change in number of species or a defined percentage change in land-use. This result may indicate that there is a part-whole bias in our set of studies implying that respondents valued a more inclusive category rather than the individual good or attribute framed in the study (Hanley et al., 1998). Other methodological variables such as surveys instead of interviews and text instead of pictures lead to a lower willingness to pay. Other meta-analyses controlling for these variables show mixed results. While some studies also show a reduction in the willingness to pay in surveys compared to interviews (Rolfe et al., 2015), there is little evidence that the mode of questionnaire in general affects willingness to pay estimates (e.g., Lindhjem and Navrud, 2011). Subroy et al. (2019) in their meta-analysis found no effect of pictures on the willingness to pay for endangered species. In this context, recent research shows that visualisation might reduce choice consistency and require more time to complete the choice tasks (Eppink et al., 2019). These control variables, 
however, should be interpreted with care due to the restricted number of studies and the categorical nature of our classification (see also Figure B2 in the Appendix, online).

Although the use of meta-analytic based value transfers is an efficient way to obtain values of local ecosystem services (Bergstrom and Taylor, 2006; Pascual et al., 2010; Richardson et al., 2015; Rolfe et al., 2015), our analysis does not identify benefit transfer relationships, since we lack the necessary spatial dimensions for both the values and the explanatory variables. However, our meta-analysis does provide important information for holistic analysis of cultural ES and the development of benefit transfer functions in mapping and modelling studies (e.g. Burkhard et al., 2013; Plieninger et al., 2013; van Berkel and Verburg, 2014).

Our findings have two direct implications for future studies addressing the valuation of grasslands, e.g. in cost-benefit analysis of conservation and agri-environmental measures. First, our results show that the switch from cropland to grassland does not automatically lead to an increase in the landscape value as implied by Ciaian and Gomez y Paloma (2011). In this context, recent literature also shows that the initial land-use and land cover configuration have important impacts on peoples' willingness to pay (Sagebiel et al., 2017) and that grassland conservation may be most effective in simple, i.e. non-complex and non-heterogeneous landscapes (Tscharntke et al., 2012). We were unable to consider the initial configuration of land-uses in the different studies. However, the high variability of willingness to pay with respect to switches from cropland to grassland implies that further research should address the direction of change in economic assessments of grassland cultural ES and thus the initial land-use and land cover composition (see also van Zanten et al., 2014).

Second, our findings suggest that peoples' willingness to pay is higher for less-intensive grassland use in mountain regions compared to both the prevention of land abandonment and lessintensive grassland use in the lowlands. Our results thus imply that the prevention of land abandonment would provide additional value if the corresponding grassland management strategy included traditional management activities and/or the preservation of biodiversity and cultural heritage aspects of grassland ES. Current trends in the European Alps, however, show a decline in traditional land-use and grassland management (Brunner et al., 2017; Marini et al., 2011; Schirpke et al., 2017). Up until now, literature has neglected this aspect and it really must be considered in future attempts to estimate and transfer the monetary value of grasslands. In addition, it should also be an important factor in other (more holistic) methodological approaches addressing the valuation of grasslands. 
In the context of policy design, efficient support for permanent grassland depends essentially on the targeting of corresponding policy measures to achieve a specific goal (van Tongeren, 2008). Permanent grassland is often seen as an important measure to provide multiple ecosystem services jointly (Manning et al., 2018). In this respect, our findings underline the spatial component of targeted support for grassland ecosystem services (Engel, 2016). Support of permanent grasslands per se does not automatically promote the provision of those cultural ES that are valued by the public, especially in crop dominated agricultural landscapes. Moreover, the support of less intensive grassland in mountain regions could generate synergies between the prevention of land abandonment and the provision of cultural heritage values and biodiversity conservation. Policies addressing land abandonment in these mountain regions could reinforce the value of cultural ES by including cultural heritage aspects in their design.

\section{Supporting Information}

Additional supporting information may be found in the online version of this article at the publisher's website:

Appendix A: Data

Appendix B: Sensitivity analysis and robustness checks

Appendix C: $\mathrm{R}$ code

Appendix D: PRISMA checklist 


\section{References}

Albert, C., C. Schröter-Schlaack, B. Hansjürgens, A. Dehnhardt, R. Döring, H. Job, J. Köppel, S. Krätzig, B. Matzdorf, M. Reutter, S. Schaltegger, M. Scholz, M. Siegmund-Schultze, H. Wiggering, M. Woltering and C. von Haaren, 'An economic perspective on land use decisions in agricultural landscapes: Insights from the TEEB Germany Study', Ecosystem Services, Vol. 25, (2017) pp. 69-78.

Allan, E., P. Manning, F. Alt, J. Binkenstein, S. Blaser, N. Blüthgen, S. Böhm, F. Grassein, N. Hölzel, H. Klaus Valentin, T. Kleinebecker, E.K. Morris, Y. Oelmann, D. Prati, C. Renner Swen, C. Rillig Matthias, M. Schaefer, M. Schloter, B. Schmitt, I. Schöning, M. Schrumpf, E. Solly, E. Sorkau, J. Steckel, I. Steffen-Dewenter, B. Stempfhuber, M. Tschapka, N. Weiner Christiane, W. Weisser Wolfgang, M. Werner, C. Westphal, W. Wilcke, M. Fischer and J. Knops, 'Land use intensification alters ecosystem multifunctionality via loss of biodiversity and changes to functional composition', Ecology Letters, Vol. 18, (2015) pp. 834-843.

Baumgart, K. Bewertung landschaftsrelevanter Projekte im Schweizer Alpenraum die Methode der Discrete-Choice-Experimente (Bern: Verlag des Geographischen Instituts der Universität Bern, 2005).

Bengtsson, J., J.M. Bullock, B. Egoh, C. Everson, T. Everson, T. O'Connor, P.J. O'Farrell, H.G. Smith and R. Lindborg, 'Grasslands - more important for ecosystem services than you might think', Ecosphere, Vol. 10, (2019) pp. 1-20.

Bergstrom, J.C. and L.O. Taylor, 'Using meta-analysis for benefits transfer: Theory and practice', Ecological Economics, Vol. 60, (2006) pp. 351-360.

Bernués, A., T. Rodríguez-Ortega, R. Ripoll-Bosch and F. Alfnes, 'Socio-cultural and economic valuation of ecosystem services provided by Mediterranean mountain agroecosystems', PLoS ONE, Vol. 9, (2014).

Blair, J., J. Nippert and J. Briggs, 'Grassland Ecology', in R.K. Monson (ed.), Ecology and the Environment (New York, NY: Springer New York, 2014), pp. 389-423.

Borresch, R., S. Maas, K. Schmitz and P.M. Schmitz, 'Modelling the value of a multifunctional landscape-A discrete choice experiment', International Association of Agricultural Economists (IAAE) Conference (Beijing, China, 2009). 
Brander, L.M. and Koetse, M. 'The value of urban open space: Meta-analyses of contingent valuation and hedonic pricing results', Journal of Environmental Management, Vol. 92, (2011), pp. 2763-2773.

Brunner, S.H., R. Huber and A. Grêt-Regamey, 'Mapping uncertainties in the future provision of ecosystem services in a mountain region in Switzerland', Regional Environmental Change, (2017) pp. 1-13.

Bullock, C.H. and J. Kay, 'Preservation and change in the upland landscape: the public benefits of grazing management', Journal of Environmental Planning and Management, Vol. 40, (1997) pp. 315-334.

Burkhard, B., N. Crossman, S. Nedkov, K. Petz and R. Alkemade, 'Mapping and modelling ecosystem services for science, policy and practice', Ecosystem Services, Vol. 4, (2013) pp. 1-3.

Cameron, A.C., J.B. Gelbach and D.L. Miller, 'Robust inference with multiway clustering', Journal of Business \& Economic Statistics, Vol. 29, (2011) pp. 238-249.

Campbell, D., 'Willingness to pay for rural landscape improvements: Combining mixed logit and random-effects models', Journal of Agricultural Economics, Vol. 58, (2007) pp. $467-483$.

Campbell, D., W.G. Hutchinson and R. Scarpa, 'Using choice experiments to explore the spatial distribution of willingness to pay for rural landscape improvements', Environment and Planning A: Economy and Space, Vol. 41, (2009) pp. 97-111.

Carson, R.T. and J.J. Louviere, 'A common nomenclature for stated preference elicitation approaches', Environmental and Resource Economics, Vol. 49, (2011) pp. 539-559.

Christie, M. and M. Rayment, 'An economic assessment of the ecosystem service benefits derived from the SSSI biodiversity conservation policy in England and Wales', Ecosystem Services, Vol. 1, (2012) pp. 70-84.

Ciaian, P. and S. Gomez y Paloma, 'The value of EU agricultural landscape', Agricultural \& Applied Economics Association's 2011 AAEA \& NAREA Joint Annual Meeting (Pittsburg, Pennsylvania, 2011).

Cocca, G., E. Sturaro, L. Gallo and M. Ramanzin, 'Is the abandonment of traditional livestock farming systems the main driver of mountain landscape change in Alpine areas?' Land Use Policy, Vol. 29, (2012) pp. 878-886. 
Dallimer, M., J.B. Jacobsen, T.H. Lundhede, K. Takkis, M. Giergiczny and B.J. Thorsen, 'Patriotic values for public goods: Transnational trade-offs for biodiversity and ecosystem services?' Bioscience, Vol. 65, (2015) pp. 33-42.

Daniel, T.C., A. Muhar, A. Arnberger, O. Aznar, J.W. Boyd, K.M.A. Chan, R. Costanza, T. Elmqvist, C.G. Flint, P.H. Gobster, A. Grêt-Regamey, R. Lave, S. Muhar, M. Penker, R.G. Ribe, T. Schauppenlehner, T. Sikor, I. Soloviy, M. Spierenburg, K. Taczanowska, J. Tam and A. von der Dunk, 'Contributions of cultural services to the ecosystem services agenda', Proceedings of the National Academy of Sciences, Vol. 109, (2012) pp. 8812-8819.

De Salvo, M. and G. Signorello, 'Non-market valuation of recreational services in Italy: a metaanalysis', Ecosystem Services, Vol. 16, (2015) pp. 47-62.

Drake, L., 'The non-market value of the Swedish agricultural landscape', European Review of Agricultural Economics, Vol. 19, (1992) pp. 351-364.

Elmqvist, T., E. Maltby, T. Barker, M. Mortimer, C. Perrings, J. Aronson, R. De Groot, A. Fitter, G. Mace and J. Norberg, 'Biodiversity, ecosystems and ecosystem services', in P. Kumar (ed.), The Economics of Ecosystems and Biodiversity: Ecological and Economic Foundations (London: Routledge, 2010), pp. 41-111.

Engel, S., 'The devil in the detail: a practical guide on designing payments for environmental services', International Review of Environmental and Resource Economics , Vol. 9, (2016), pp. 131-177.

Eppink, F.V., N. Hanley and S. Tucker, 'How best to present complex ecosystem information in stated preference studies?' Ecological Economics, Vol. 158, (2019) pp. 20-25.

Estel, S., S. Mader, C. Levers, P. Verburg, H., M. Baumann and T. Kuemmerle, 'Combining satellite data and agricultural statistics to map grassland management intensity in Europe', Environmental Research Letters, Vol. 13, (2018) pp. 1-10.

Eurostat. Reference European System of National and Regional Accounts (Brussels: Eurostat, 2019). Available online at: http://ec.europa.eu/eurostat/web/purchasing-power-parities/data/database; ESA 2010 (accessed May 2019).

EVRI. The Environmental Valuation Reference Inventory (Gatineau: Environment Canada EVRI, 2018). Available online at: www.evri.ca/en (accessed July 2018). 
Ezebilo, E.E., 'Economic value of a non-market ecosystem service: an application of the travel cost method to nature recreation in Sweden', International Journal of Biodiversity Science, Ecosystem Services \& Management, Vol. 12, (2016), pp. 314-327.

Finger, R. and N. Buchmann, 'An ecological economic assessment of risk-reducing effects of species diversity in managed grasslands', Ecological Economics, Vol. 110, (2015) pp. 89-97.

Finger, R., 'Revisiting the evaluation of robust regression techniques for crop yield data detrending', American Journal of Agricultural Economics, Vol. 92, (2010) pp. 205-211.

Fisher, B., K. Turner, M. Zylstra, R. Brouwer, R. Groot, S. Farber, P. Ferraro, R. Green, D. Hadley, J. Harlow, P. Jefferiss, C. Kirkby, P. Morling, S. Mowatt, R. Naidoo, J. Paavola, B. Strassburg, D. Yu and A. Balmford, 'Ecosystem services and economic theory: integration for policy-relevant research', Ecological Applications, Vol. 18, (2008) pp. 2050 $-2067$.

Fox, J. and G. Monette, 'Generalized collinearity diagnostics', Journal of the American Statistical Association, Vol. 87, (1992) pp. 178-183.

Frélichová, J., D. Vačkář, A. Pártl, B. Loučková, Z.V. Harmáčková and E. Lorencová, 'Integrated assessment of ecosystem services in the Czech Republic', Ecosystem Services, Vol. 8, (2014) pp. 110-117.

Fuller, R.A., K.N. Irvine, P. Devine-Wright, P.H. Warren and K.J. Gaston, 'Psychological benefits of greenspace increase with biodiversity', Biology Letters, Vol. 3, (2007) pp. 390394.

Garrod, G.D. and K.G. Willis, 'Valuing the benefits of the South Downs environmental sensitive area', Journal of Agricultural Economics, Vol. 46, (1995) pp. 160-173.

Gómez-Baggethun, E. and M. Ruiz-Pérez, 'Economic valuation and the commodification of ecosystem services', Progress in Physical Geography: Earth and Environment, Vol. 35, (2011) pp. 613-628.

Grêt-Regamey, A., A. Walz and P. Bebi, 'Valuing ecosystem services for sustainable landscape planning in Alpine regions', Mountain Research and Development, Vol. 28, (2008) pp. $156-165$. 
Hahn, T., M. Heinrup and R. Lindborg, 'Landscape heterogeneity correlates with recreational values: a case study from Swedish agricultural landscapes and implications for policy', Landscape Research, Vol. 43, (2018) pp. 696-707.

Hanley, N., D. MacMillan, R.E. Wright, C. Bullock, I. Simpson, D. Parsisson and B. Crabtree, 'Contingent valuation versus choice experiments: Estimating the benefits of environmentally sensitive areas in Scotland', Journal of Agricultural Economics, Vol. 49, (1998) pp. 1-15.

Harrison, P.A., P.M. Berry, G. Simpson, J.R. Haslett, M. Blicharska, M. Bucur, R. Dunford, B. Egoh, M. Garcia-Llorente, N. Geamănă, W. Geertsema, E. Lommelen, L. Meiresonne and F. Turkelboom, 'Linkages between biodiversity attributes and ecosystem services: A systematic review', Ecosystem Services, Vol. 9, (2014) pp. 191-203.

Hasund, K.P., M. Kataria and C.J. Lagerkvist, 'Valuing public goods of the agricultural landscape: a choice experiment using reference points to capture observable heterogeneity', Journal of Environmental Planning and Management, Vol. 54, (2011) pp. 31-53.

Hernández-Morcillo, M., T. Plieninger and C. Bieling, 'An empirical review of cultural ecosystem service indicators', Ecological Indicators, Vol. 29, (2013) pp. 434-444.

Hirsch, S., 'Successful in the long run: a meta-regression analysis of persistent firm profits', Journal of Economic Surveys, Vol. 32, (2018) pp. 23-49.

Howley, P., S. Hynes and C. O'Donoghue, 'The citizen versus consumer distinction: an exploration of individuals' preferences in Contingent Valuation studies', Ecological Economics, Vol. 69, (2010) pp. 1524-1531.

Huber, R., M. Hunziker and B. Lehmann, 'Valuation of agricultural land-use scenarios with choice experiments: a political market share approach', Journal of Environmental Planning and Management, Vol. 54, (2011) pp. 93-113.

Huber, R., R.S. Snell, F. Monin, S.H. Brunner, D.R. Schmatz and R. Finger "Interaction effects of targeted agri-environmental payments on non-marketed goods and services under climate change in a mountain region." Land Use Policy, Vol. 66, (2017) pp. 49-60.

Hunziker, M., P. Felber, K. Gehring, M. Buchecker, N. Bauer and F. Kienast, 'Evaluation of landscape change by different social groups', Mountain Research and Development, Vol. 28, (2008) pp. 140-147. 
Hynes, S. and D. Campbell, 'Estimating the welfare impacts of agricultural landscape change in Ireland: a choice experiment approach', Journal of Environmental Planning and Management, Vol. 54, (2011) pp. 1019-1039.

Hynes, S., D. Campbell and P. Howley, 'A holistic vs. an attribute-based approach to agrienvironmental policy valuation: Do welfare estimates differ?' Journal of Agricultural Economics, Vol. 62, (2011) pp. 305-329.

Jacobsen, J.B. and N. Hanley, 'Are there income effects on global willingness to pay for biodiversity conservation?' Journal of Environmental Resource Economics, Vol. 43, (2009) pp. 137-160.

Johnston, R.J., K.J. Boyle, W. Adamowicz, J. Bennett, R. Brouwer, T.A. Cameron, W.M. Hanemann, N. Hanley, M. Ryan, R. Scarpa, R. Tourangeau and C.A. Vossler, 'Contemporary guidance for stated preference studies', Journal of the Association of Environmental and Resource Economists, Vol. 4, (2017) pp. 319-405.

Junge, X., K.A. Jacot, A. Bosshard and P. Lindemann-Matthies, 'Swiss people's attitudes towards field margins for biodiversity conservation', Journal for Nature Conservation, Vol. 17, (2009) pp. 150-159.

Junge, X., P. Lindemann-Matthies, M. Hunziker and B. Schüpbach, 'Aesthetic preferences of non-farmers and farmers for different land-use types and proportions of ecological compensation areas in the Swiss lowlands', Biological Conservation, Vol. 144, (2011) pp. $1430-1440$.

Komossa, F., E.H. van der Zanden, C.J.E. Schulp and P.H. Verburg, 'Mapping landscape potential for outdoor recreation using different archetypical recreation user groups in the European Union', Ecological Indicators, Vol. 85, (2018) pp. 105-116.

Křrumalová, V., 'Evaluation of chosen benefits on environment and landscape coming from Czech agriculture', Agricultural Economics-Czech, Vol. 48, (2002) pp. 13-17.

Kvakkestad, V., P.K. Rørstad and A. Vatn "Norwegian farmers' perspectives on agriculture and agricultural payments: Between productivism and cultural landscapes." Land Use Policy, Vol. 42, (2015) pp. 83-92.

Lefebvre, M., M. Espinosa, S. Gomez y Paloma, M.L. Paracchini, A. Piorr and I. Zasada "Agricultural landscapes as multi-scale public good and the role of the Common Agricultural Policy." Journal of Environmental Planning and Management, Vol. 58, (2015) pp. 2088-2112. 
Lindemann-Matthies, P., R. Briegel, B. Schüpbach and X. Junge, 'Aesthetic preference for a Swiss alpine landscape: The impact of different agricultural land-use with different biodiversity', Landscape and Urban Planning, Vol. 98, (2011) pp. 99-109.

Lindhjem, H. and S. Navrud, 'Are internet surveys an alternative to face-to-face interviews in contingent valuation?' Ecological Economics, Vol. 70, (2011) pp. 1628-1637.

Macaskill, P., D. Walter Stephen and L. Irwig, 'A comparison of methods to detect publication bias in meta-analysis', Statistics in Medicine, Vol. 20, (2001) pp. 641-654.

Mack, G. and R. Huber, 'On-farm compliance costs and N surplus reduction of mixed dairy farms under grassland-based feeding systems', Agricultural Systems, Vol. 154, (2017) pp. 34-44.

Mahieu, P.-A., H. Andersson, O. Beaumais, R. Crastes dit Sourd, S. Hess and F.-C. Wolff, 'Stated preferences: a unique database composed of 1657 recent published articles in journals related to agriculture, environment, or health', Review of Agricultural, Food and Environmental Studies, Vol. 98, (2017) pp. 201-220.

Malinga, R., L.J. Gordon, G. Jewitt and R. Lindborg, 'Mapping ecosystem services across scales and continents - A review', Ecosystem Services, Vol. 13, (2015) pp. 57-63.

Manning, P., F. van der Plas, S. Soliveres, E. Allan, F.T. Maestre, G. Mace, M.J. Whittingham and M. Fischer, 'Redefining ecosystem multifunctionality', Nature Ecology \& Evolution, Vol. 2, (2018) pp. 427-436.

Marini, L., S. Klimek and A. Battisti, 'Mitigating the impacts of the decline of traditional farming on mountain landscapes and biodiversity: a case study in the European Alps', Environmental Science \& Policy, Vol. 14, (2011) pp. 258-267.

Marzetti, S., M. Disegna, G. Villani and M. Speranza, 'Conservation and recreational values from semi-natural grasslands for visitors to two Italian parks', Journal of Environmental Planning and Management, Vol. 54, (2011) pp. 169-191.

Mazzocchi, C. and G. Sali, 'Assessing the value of pastoral farming in the Alps using choice experiments: Evidence for public policies and management', Journal of Environmental Planning and Management, (2018) pp. 1-16.

MEA Millennium Ecosystem Assessment. Ecosystems and Human Well-being (Washington, DC: Island Press, 2005). 
Meyerhoff, J., D. Angeli and V. Hartje, 'Valuing the benefits of implementing a national strategy on biological diversity_The case of Germany', Environmental Science \& Policy, Vol. 23, (2012) pp. 109-119.

Moher, D., L. Shamseer, M. Clarke, D. Ghersi, A. Liberati, M. Petticrew, P. Shekelle, L.A. Stewart and P.-P. Group, 'Preferred reporting items for systematic review and metaanalysis protocols (PRISMA-P) 2015 statement', Systematic Reviews, Vol. 4, (2015) pp. 1.

Moran, D., A. McVittie, D.J. Allcroft and D.A. Elston, 'Quantifying public preferences for agrienvironmental policy in Scotland: a comparison of methods', Ecological Economics, Vol. 63, (2007) pp. 42-53.

Nelson, J.P. and P.E. Kennedy, 'The use (and abuse) of meta-analysis in environmental and natural resource economics: an assessment', Environmental and Resource Economics, Vol. 42, (2009) pp. 345-377.

Ode, Å., M.S. Tveit and G. Fry, 'Capturing landscape visual character using indicators: Touching base with landscape aesthetic theory', Landscape Research, Vol. 33, (2008) pp. 89117.

Pascual, U., R. Muradian, L. Brander, E. Gómez-Baggethun, B. Martín-López, M. Verma, P. Armsworth, M. Christie, H. Cornelissen and F. Eppink, 'The economics of valuing ecosystem services and biodiversity', in P. Kumar (ed.), TEEB-Ecological and Economic Foundation, London and Washington: Earthscan, Chapter 5, (2010) pp. 188-257.

Pe'er, G., L.V. Dicks, P. Visconti, R. Arlettaz, A. Báldi, T.G. Benton, S. Collins, M. Dieterich, R.D. Gregory, F. Hartig, K. Henle, P.R. Hobson, D. Kleijn, R.K. Neumann, T. Robijns, J. Schmidt, A. Shwartz, W.J. Sutherland, A. Turbé, F. Wulf and A.V. Scott, 'EU agricultural reform fails on biodiversity', Science, Vol. 344, (2014) pp. 1090-1092.

Petrolia, D.R., M.G. Interis and J. Hwang, 'Single-choice, repeated-choice, and best-worst scaling elicitation formats: Do results differ and by how much?' Environmental and Resource Economics, Vol. 69, (2018) pp. 365-393.

Plieninger, T., C. Bieling, N. Fagerholm, A. Byg, T. Hartel, P. Hurley, C.A. López-Santiago, N. Nagabhatla, E. Oteros-Rozas, C.M. Raymond, D. van der Horst and L. Huntsinger, 'The role of cultural ecosystem services in landscape management and planning', Current Opinion in Environmental Sustainability, Vol. 14, (2015) pp. 28-33. 
Plieninger, T., S. Dijks, E. Oteros-Rozas and C. Bieling, 'Assessing, mapping, and quantifying cultural ecosystem services at community level', Land Use Policy, Vol. 33, (2013) pp. $118-129$.

Quétier, F., F. Rivoal, P. Marty, J. de Chazal, W. Thuiller and S. Lavorel, 'Social representations of an alpine grassland landscape and socio-political discourses on rural development', Regional Environmental Change, Vol. 10, (2010) pp. 119-130.

Rakotonarivo, O.S., M. Schaafsma and N. Hockley, 'A systematic review of the reliability and validity of discrete choice experiments in valuing non-market environmental goods', Journal of Environmental Management, Vol. 183, (2016) pp. 98-109.

Randall, A., 'Valuing the outputs of multifunctional agriculture', European Review of Agricultural Economics, Vol. 29, (2002) pp. 289-307.

Rewitzer, S., R. Huber, A. Grêt-Regamey and J. Barkmann, 'Economic valuation of cultural ecosystem service changes to a landscape in the Swiss Alps', Ecosystem Services, Vol. 26, (2017) pp. 197-208.

Richardson, L. and J. Loomis, 'The total economic value of threatened, endangered and rare species: an updated meta-analysis', Ecological Economics, Vol. 68, (2009) pp. 1535 1548.

Richardson, L., J. Loomis, T. Kroeger and F. Casey, 'The role of benefit transfer in ecosystem service valuation', Ecological Economics, Vol. 115, (2015) pp. 51-58.

Rolfe, J., R. Brouwer and R.J. Johnston, 'Meta-analysis: Rationale, issues and applications', in R.J. Johnston, J. Rolfe, R.S. Rosenberger and R. Brouwer (eds.), Benefit Transfer of Environmental and Resource Values: A Guide for Researchers and Practitioners (Dordrecht: Springer Netherlands, 2015), pp. 357-381.

Sagebiel, J., K. Glenk and J. Meyerhoff, 'Spatially explicit demand for afforestation', Forest Policy and Economics, Vol. 78, (2017) pp. 190-199.

Schägner, J.P., L. Brander, J. Maes and V. Hartje, 'Mapping ecosystem services' values: Current practice and future prospects', Ecosystem Services, Vol. 4, (2013) pp. 33-46.

Schägner, J.P., L. Brander, M.L. Paracchini, J. Maes, F. Gollnow and B. Bertzky, 'Spatial dimensions of recreational ecosystem service values: a review of meta-analyses and a combination of meta-analytic value-transfer and GIS', Ecosystem Services, Vol. 31, Part C, (2018) pp. 395-409. 
Schaich, H., C. Bieling and T. Plieninger, 'Linking ecosystem services with cultural landscape research', GAIA - Ecological Perspectives for Science and Society, Vol. 19, (2010) pp. $269-277$.

Schenk, A., M. Hunziker and F. Kienast, 'Factors influencing the acceptance of nature conservation measures-a qualitative study in Switzerland', Journal of Environmental Management, Vol. 83, (2007) pp. 66-79.

Schirpke, U., C. Meisch, T. Marsoner and U. Tappeiner, 'Revealing spatial and temporal patterns of outdoor recreation in the European Alps and their surroundings', Ecosystem Services, Vol. 31, Part C, (2018) pp. 336-350.

Schirpke, U., F. Timmermann, U. Tappeiner and E. Tasser, 'Cultural ecosystem services of mountain regions: Modelling the aesthetic value', Ecological Indicators, Vol. 69, (2016) pp. 78-90.

Schirpke, U., M. Kohler, G. Leitinger, V. Fontana, E. Tasser and U. Tappeiner, 'Future impacts of changing land-use and climate on ecosystem services of mountain grassland and their resilience', Ecosystem Services, Vol. 26, (2017) pp. 79-94.

Schläpfer, F. and M. Schmitt, 'Anchors, endorsements, and preferences: s field experiment', Resource and Energy Economics, Vol. 29, (2007) pp. 229-243.

Schläpfer, F., 'Stated preferences for public services: a classification and survey of approaches', Journal of Economic Surveys, Vol. 31, (2017) pp. 258-280.

Schmitt, M., F. Schläpfer and A. Roschewitz Bewertung von Landschaftsveränderungen im Schweizer Mittelland aus Sicht der Bevölkerung eine Anwendung der Choice-Experiment-Methode (Birmensdorf, Eidgenössische Forschungsanstalt für Wald Schnee und Landschaft WSL, 2005).

Schmitz, K. Die Bewertung von Multifunktionalität der Landschaft mit diskreten Choice Experimenten (Zentrum für internationale Entwicklungs- und Umweltforschung (ZEU) Justus-Liebig-Universität Giessen, 2006), pp. 1-281.

Schmitz, K., M.P. Schmitz and T.C. Wronka, 'Bewertung von Landschaftsfunktionen mit choice experiments', Agrarwirtschaft, Vol. 52, (2003) pp. 379-389.

Schröter, M., E.H. van der Zanden, A.P.E. van Oudenhoven, R.P. Remme, H.M. Serna-Chavez, R.S. de Groot and P. Opdam, 'Ecosystem services as a contested concept: a synthesis of critique and counter-arguments', Conservation Letters, Vol. 7, (2014) pp. 514-523. 
Schüpbach, B., K. Zgraggen and E. Szerencsits, 'Incentives for low-input land-use types and their influence on the attractiveness of landscapes', Journal of Environmental Management, Vol. 89, (2008) pp. 222-233.

Stanley, T.D., 'Beyond Publication Bias', Journal of Economic Surveys, Vol. 19, (2005) pp. 309-345.

Stanley, T.D., H. Doucouliagos, M. Giles, J.H. Heckemeyer, R.J. Johnston, P. Laroche, J.P. Nelson, M. Paldam, J. Poot, G. Pugh, R.S. Rosenberger and K. Rost, 'Meta-analysis of economics research reporting guidelines', Journal of Economic Surveys, Vol. 27, (2013) pp. 390-394.

Sterne, J.A.C., D. Gavaghan and M. Egger, 'Publication and related bias in meta-analysis', Journal of Clinical Epidemiology, Vol. 53, (2000) pp. 1119-1129.

Subroy, V., A. Gunawardena, M. Polyakov, R. Pandit and D.J. Pannell, 'The worth of wildlife: a meta-analysis of global non-market values of threatened species', Ecological Economics, Vol. 164, (2019) pp. 106-374.

Tempesta, T. and M. Thiene, 'The willingness to pay for the conservation of mountain landscape in Cortina D’Ampezzo (Italy)', Padova: Università degli Studi di Padova, (2014) pp. 1-15.

Tinch, D., S. Colombo and N. Hanley, 'The impacts of elicitation context on stated preferences for agricultural landscapes', Journal of Agricultural Economics, Vol. 66, (2015) pp. 87107.

Tscharntke, T., J.M. Tylianakis, T.A. Rand, R.K. Didham, L. Fahrig, P. Batáry, J. Bengtsson, Y. Clough, T.O. Crist, C.F. Dormann, R.M. Ewers, J. Fründ, R.D. Holt, A. Holzschuh, A.M. Klein, D. Kleijn, C. Kremen, D.A. Landis, W. Laurance, D. Lindenmayer, C. Scherber, N. Sodhi, I. Steffan-Dewenter, C. Thies, W.H. van der Putten and C. Westphal, 'Landscape moderation of biodiversity patterns and processes - eight hypotheses', Biological Reviews, Vol. 87, (2012) pp. 661-685.

van Berkel, D.B. and P.H. Verburg, 'Spatial quantification and valuation of cultural ecosystem services in an agricultural landscape', Ecological Indicators, Vol. 37, (2014) pp. 163174.

van Zanten, B.T., P.H. Verburg, M.J. Koetse and P.J.H. van Beukering, 'Preferences for European agrarian landscapes: a meta-analysis of case studies', Landscape and Urban Planning, Vol. 132, (2014) pp. 89-101. 
Willis, K.G. and G.D. Garrod, 'Assessing the value of future landscapes', Landscape and Urban Planning, Vol. 23, (1992) pp. 17-32.

Wüstemann, H., J. Meyerhoff, M. Rühs, A. Schäfer and V. Hartje, 'Financial costs and benefits of a program of measures to implement a National Strategy on Biological Diversity in Germany', Land Use Policy, Vol. 36, (2014) pp. 307-318.

Yadav, L., T.M. van Rensburg and H. Kelley, 'Comparing the conventional stated preference valuation technique with a prediction approach", 84th Annual Conference, March 29-31 (Edinburgh, Scotland: Agricultural Economics Society, 2010).

Zoderer, B.M., E. Tasser, K.-H. Erb, P.S. Lupo Stanghellini and U. Tappeiner, 'Identifying and mapping the tourists' perception of cultural ecosystem services: a case study from an Alpine region', Land Use Policy, Vol. 56, (2016) pp. 251-261. 